\title{
Information content of corporate reports of US medical companies
}

\author{
Julia Kuznetsova* \\ Branch of Kuzbass State Technical University named after T.F. Gorbachev in the city of \\ Novokuznetsk, Ordzhonikidze Str., 8a, 654000 Novokuznetsk, Russia
}

\begin{abstract}
The document shows that corporate reporting is not only a source of information about the current state, results and trends of the company's development, but also a thing that transfers its image to the external and internal environment. It is determined that the transfer of a charitable image to external recipients of such information about the companies' activity operating in the social services is especially important. Based on the analysis of $10-\mathrm{K}$ form reports in the 10 largest medical companies in the United States there were revealed information blocks, focusing on which the consumer will pay attention to a particular company, and not a competitor's company.
\end{abstract}

\section{Introduction}

Corporate reporting is a channel that connects the company with all parties interested in its activities, both in the external and internal environment, as well as one of the main directions for improving the corporate governance system. The corporate reporting system differs in Russia and abroad, both in the composition of documents and their information content. The main requirement for reporting in the United States is the information utility for the user to make certain decisions. Reporting regulations affect a limited number of organizations: this includes joint-stock companies and enterprises in regulated industries. For others, the form and composition of reporting is determined by management independently. However when submitting financial reporting it is important to obtain an appropriate auditor's opinion [1]. A distinctive feature of corporate reports of American companies is not their form, but their qualitative and quantitative information content [2]. According to the Association of Chartered Certified Accountants (ACCA), competent corporate reporting can influence stock prices, help businesses gain access to financial resources, enter into contracts with customers and suppliers, attract employees [3], and its quality indicators are: 1) up-to-dateness and relevance of the material; 2) completeness of the information provided; 3) reliability; 4) data comparability; 5) ability to verify data; 6) timeliness; 7) understandability. The following criteria are separated to evaluate narrative reports: future orientation, strategic focus, dependence on the object (any information that directly relates to the management object), correlation with previous years reports, research of all important aspects of the activity, and laconicism.

${ }^{*}$ Corresponding author: acanaria2005@yandex.ru 
One of the reporting forms is form 10-K, which is provided by American companies to the Securities and Exchange Commission. Preparation of this document is necessary for all US companies. This report consists of 4 parts and 15 sections: 1) business characteristics (risk factors are highlighted separately); 2) location of offices; 3) court proceedings; 4) disclosure of security information; 5) issues related to the stock market; 6) selected financial data; 7) analysis of financial condition and results of operations; 8) financial statements and additional data; 9) information about changes and disagreements with accountants on accounting issues; 10) Directorate and corporate governance; 11) management remuneration; 12) security of property of certain owners and management; 13) transactions with related persons and independence of the Director; 14) basic accounting fees and services; 15) reports and graphs on financial activities.

It appears that in order to build a positive reputation in the market of goods and services, the company should pay special attention to the quality of information parameters provided to consumers. This is even more important for those companies whose activities directly affect the quality of life of the population, i.e., those that operate in the social services. According to many foreign and domestic researchers social corporate reporting has a semiotic property to a greater extent $[4,5]$, but the same property can be attributed to global general corporate reports. J. H. Spangenberg tries to trace the feedback, suggesting that corporate reporting should contain a criterion similar in content to the human development index, formed however for the internal environment of the company (the corporate human development index) [6].

In this regard the purpose of this document was to identify and analyze the sections of the report on form $10-\mathrm{K}$ of the ten largest medical companies in the United States that can significantly influence the decision of consumers to contact this, and not another company.

\section{Research methods}

To achieve this goal, we studied the information content of the report on form $10-\mathrm{K}$ of the ten largest medical companies in the United States for the last year of the report, which is available in the public domain. Evaluation of the corporate reports content of US medical companies was carried out in 2 stages: expert evaluation of the significance of sections of form $10-\mathrm{K}$ in terms of attracting and retaining potential and existing customers; evaluation of information content of significant sections.

The significance of the form $10-\mathrm{K}$ sections was evaluated by a group of 17 Russian experts in the field of medical equipment supply and medical services. Significance is evaluated by assigning a point from 0 to 1 , where 0 is no significance, and 1 is the highest level of significance. During the assessment there was a condition that no more than three sections can receive an identical rating. The final outcome evaluation is defined as the arithmetic mean value of 17 experts' assessments.

The information content of the relevant sections was evaluated by male and female citizens at the ages from 30 to 55 who are active users of medical products and services. The number of experts was 63 people. The survey involved respondents who speak English. It was conducted in August-October 2020 via email and orally in two stages. At the first stage, respondents answered the question: what are the most important characteristics of the information provided in the report of American medical companies on form 10-K? At the second stage, the same respondents were asked to fill out a table for evaluating the information content of corporate reports of designated medical companies. The characteristics that were most frequently mentioned by respondents in the first stage of the survey were evaluated based on assigning one of the following criteria to each characteristic: B - high level of quality, $\mathrm{C}-$ medium level, $\mathrm{H}-$ low. As a result, the 
occurrence of each characteristic for all medical companies for each respondent was calculated.

\section{Evaluation of the reports information content of US medical companies}

As a result of the first stage implementation of the corporate reporting survey of US medical companies on form $10-\mathrm{K}$, the following results of expert evaluation were obtained (table 1).

Table 1. Expert evaluation of the significance of form $10-\mathrm{K}$ sections

\begin{tabular}{|c|c|c|c|c|c|c|c|c|c|c|c|c|c|c|c|c|c|c|}
\hline \multirow{2}{*}{ 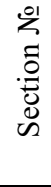 } & \multicolumn{17}{|c|}{ Expert evaluations } & \multirow{2}{*}{ 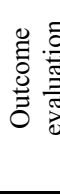 } \\
\hline & 1 & 2 & 3 & 4 & 5 & 6 & 7 & 8 & 9 & 10 & 11 & 12 & 13 & 14 & 15 & 16 & 17 & \\
\hline 1 & 1 & 0,5 & 0,7 & 0,9 & 1 & 1 & 1 & 0,6 & 0,8 & 0,9 & 1 & 0,9 & 0,6 & 0,6 & 0,7 & 0,7 & 0,8 & 0,81 \\
\hline 2 & 0,9 & 1 & 0,5 & 0,6 & 0,6 & 0,7 & 1 & 0,9 & 0,8 & 0,9 & 0,8 & 0,7 & 1 & 0,9 & 1 & 0,9 & 1 & 0,84 \\
\hline 3 & 0,8 & 0,9 & 0,9 & 0,8 & 0,8 & 0,8 & 0,7 & 0,8 & 0,9 & 0,7 & 0,8 & 0,6 & 0,8 & 0,6 & 0,8 & 1 & 0,9 & 0,80 \\
\hline 4 & 1 & 1 & 1 & 1 & 0,7 & 0,8 & 0,9 & 0,6 & 0,7 & 0,8 & 0,9 & 0,8 & 0,9 & 0,7 & 0,9 & 1 & 1 & 0,86 \\
\hline 5 & 0,5 & 0,6 & 0,8 & 0,7 & 0,6 & 0,5 & 0,5 & 0,4 & 0,6 & 0,5 & 0,6 & 0,5 & 0,5 & 0,5 & 0,7 & 0,7 & 0,5 & 0,57 \\
\hline 6 & 0,6 & 0,6 & 0,7 & 0,9 & 0,8 & 0,6 & 0,6 & 0,7 & 0,7 & 0,5 & 0,9 & 0,8 & 0,7 & 0,6 & 0,7 & 0,7 & 0,8 & 0,70 \\
\hline 7 & 0,5 & 0,7 & 0,7 & 0,7 & 0,9 & 0,5 & 0,5 & 0,6 & 0,7 & 0,6 & 0,7 & 0,7 & 0,6 & 0,7 & 0,6 & 0,6 & 0,7 & 0,65 \\
\hline 8 & 0,4 & 0,6 & 0,6 & 0,5 & 0,7 & 0,6 & 0,6 & 0,7 & 0,6 & 0,8 & 0,9 & 0,8 & 0,6 & 0,7 & 0,6 & 0,5 & 0,7 & 0,64 \\
\hline 9 & 0 & 0,1 & 0 & 0,2 & 0 & 0 & 0 & 0 & 0 & 0 & 0,2 & 0,1 & 0,1 & 0 & 0 & 0 & 0 & 0,04 \\
\hline 10 & 0,9 & 0,7 & 0,6 & 0,9 & 0,5 & 0,9 & 0,9 & 0,5 & 0,5 & 0,6 & 0,7 & 0,7 & 0,7 & 0,6 & 0,6 & 0,9 & 0,8 & 0,71 \\
\hline 11 & 0,5 & 0,4 & 0,3 & 0,3 & 0,2 & 0,3 & 0,4 & 0,4 & 0,3 & 0,2 & 0 & 0 & 0,2 & 0,2 & 0,3 & 0 & 0 & 0,24 \\
\hline 12 & 0 & 0 & 0 & 0 & 0 & 0,1 & 0,1 & 0 & 0 & 0 & 0 & 0 & 0 & 0 & 0 & 0,1 & 0 & 0,02 \\
\hline 13 & 0,1 & 0 & $\overline{0}$ & 0 & 0,1 & 0,1 & 0,1 & 0 & 0 & 0 & 0 & 0 & 0 & 0 & 0,1 & 0 & 0 & 0,03 \\
\hline 14 & 0 & 0 & 0 & 0 & 0 & 0 & 0 & 0 & 0,1 & 0,1 & 0 & 0 & 0 & 0 & 0 & 0 & 0 & 0,01 \\
\hline 15 & 0,1 & 0,2 & 0,3 & 0,2 & 0,3 & 0,1 & 0,2 & 0,1 & 0,2 & 0,1 & 0,3 & 0,1 & 0,2 & 0,1 & 0,1 & 0,2 & 0,1 & 0,17 \\
\hline
\end{tabular}

In general the experts' evaluations are consistent for each of the sections described. According to experts the sections included in the first part of the report are of the greatest importance. The greatest value from the point of view of forming the commitment of consumers to the company's products are:

1) section 4 "Disclosure of security information" $(0,86)$;

2) section 2 "Location of offices" $(0,84)$;

3) section 1 "Business characteristics" $(0,81)$.

It is determined that information about safety characteristics is important from the point of view that the consumer can be confident in the high quality of products, the process of obtaining them, as well as the absence of negative consequences of their use in the long term. The high significance of section 2 is due to the consumer's need to get information about the availability of the company's products and possible difficulties in obtaining it from the point of view of geographical and territorial features. As for the first section, based on the information provided here, the consumer forms a complete picture of the product in his mind and makes a conclusion about whether to use it or the products of another company.

The sections on accounting fees and services, operations related to the company's activities, the independence of the Director, and the security of management's property are considered the least valuable for the consumer.

At the second stage of the survey information from these sections was analyzed in the reports of the 10 largest medical companies in the United States (table 2). 
Table 2. Expert evaluation of the significance of form $10-\mathrm{K}^{*}$ sections

\begin{tabular}{|c|c|c|c|c|c|c|c|c|c|c|}
\hline $\begin{array}{l}\text { Characteristic } \\
\text { s of the } \\
\text { information } \\
\text { provided }\end{array}$ & 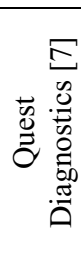 & 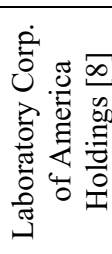 & 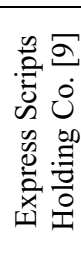 & 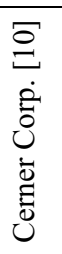 & $\begin{array}{l}\Xi \\
\Xi \\
\Xi \\
\Xi \\
\stackrel{\Xi}{\Xi} \\
\stackrel{\Xi}{\Xi}\end{array}$ & 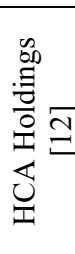 & 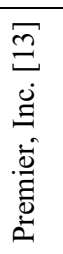 & 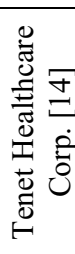 & 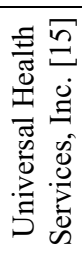 & 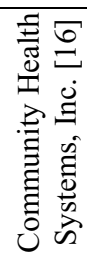 \\
\hline $\begin{array}{l}\text { Completenes } \\
\text { s of } \\
\text { information } \\
\text { provided }\end{array}$ & $\begin{array}{c}39 \mathrm{H} \\
50 \mathrm{C} \\
58 \mathrm{~B} \\
* *\end{array}$ & $\begin{array}{l}40 \mathrm{H} \\
63 \mathrm{~B} \\
60 \mathrm{C}\end{array}$ & $\begin{array}{l}45 \mathrm{H} \\
38 \mathrm{C} \\
51 \mathrm{~B}\end{array}$ & $\begin{array}{l}30 \mathrm{C} \\
45 \mathrm{C} \\
54 \mathrm{~B}\end{array}$ & $\begin{array}{l}35 \mathrm{H} \\
30 \mathrm{C} \\
45 \mathrm{~B}\end{array}$ & $\begin{array}{l}30 \mathrm{H} \\
45 \mathrm{C} \\
60 \mathrm{~B}\end{array}$ & $\begin{array}{l}45 \mathrm{C} \\
40 \mathrm{C} \\
59 \mathrm{C}\end{array}$ & $\begin{array}{l}39 \mathrm{H} \\
30 \mathrm{C} \\
48 \mathrm{~B}\end{array}$ & $\begin{array}{l}46 \mathrm{C} \\
44 \mathrm{C} \\
59 \mathrm{C}\end{array}$ & $\begin{array}{l}34 \mathrm{~B} \\
40 \mathrm{C} \\
47 \mathrm{~B}\end{array}$ \\
\hline $\begin{array}{l}\text { Accessibility } \\
\text { of the } \\
\text { presentation } \\
\text { to the } \\
\text { mainstream } \\
\text { population }\end{array}$ & $\begin{array}{l}46 \mathrm{C} \\
55 \mathrm{~B} \\
60 \mathrm{~B}\end{array}$ & $\begin{array}{l}40 \mathrm{H} \\
50 \mathrm{C} \\
61 \mathrm{C}\end{array}$ & $\begin{array}{l}39 \mathrm{H} \\
45 \mathrm{C} \\
50 \mathrm{~B}\end{array}$ & $\begin{array}{l}35 \mathrm{C} \\
50 \mathrm{C} \\
50 \mathrm{C}\end{array}$ & $\begin{array}{l}39 \mathrm{H} \\
30 \mathrm{C} \\
50 \mathrm{C}\end{array}$ & $\begin{array}{l}34 \mathrm{H} \\
49 \mathrm{C} \\
58 \mathrm{C}\end{array}$ & $\begin{array}{l}40 \mathrm{C} \\
40 \mathrm{C} \\
41 \mathrm{C}\end{array}$ & $\begin{array}{l}41 \mathrm{~B} \\
39 \mathrm{C} \\
30 \mathrm{H}\end{array}$ & $\begin{array}{l}37 \mathrm{~B} \\
39 \mathrm{C} \\
54 \mathrm{~B}\end{array}$ & $\begin{array}{l}42 \mathrm{C} \\
40 \mathrm{C} \\
43 \mathrm{~B}\end{array}$ \\
\hline $\begin{array}{l}\text { Absence of } \\
\text { the } \\
\text { possibility of } \\
\text { dual } \\
\text { understandin } \\
\text { g of } \\
\text { information }\end{array}$ & $\begin{array}{l}47 \mathrm{C} \\
50 \mathrm{C} \\
50 \mathrm{~B}\end{array}$ & $\begin{array}{l}35 \mathrm{C} \\
30 \mathrm{C} \\
48 \mathrm{C}\end{array}$ & $\begin{array}{l}30 \mathrm{C} \\
31 \mathrm{H} \\
40 \mathrm{C}\end{array}$ & $\begin{array}{l}31 \mathrm{C} \\
30 \mathrm{C} \\
42 \mathrm{C}\end{array}$ & $\begin{array}{l}36 \mathrm{C} \\
30 \mathrm{C} \\
41 \mathrm{C}\end{array}$ & $\begin{array}{l}45 \mathrm{C} \\
39 \mathrm{C} \\
32 \mathrm{H}\end{array}$ & $\begin{array}{l}39 \mathrm{C} \\
40 \mathrm{C} \\
39 \mathrm{C}\end{array}$ & $\begin{array}{l}42 \mathrm{C} \\
49 \mathrm{C} \\
31 \mathrm{C}\end{array}$ & $\begin{array}{l}39 \mathrm{C} \\
48 \mathrm{C} \\
37 \mathrm{C}\end{array}$ & $\begin{array}{l}43 \mathrm{C} \\
50 \mathrm{C} \\
34 \mathrm{~B}\end{array}$ \\
\hline
\end{tabular}

* for each company, the results of evaluating the characteristics that scored the highest number of points among respondents are given (for example, 39H means that 39 people described the completeness of providing information by Quest Diagnostics as low)

** the first value is the evaluation of section 4, the second - section 2, the third - section 1

Of the three analyzed characteristics the completeness of providing information about companies' activities is the highest. Most often, security information is provided by a separate link that consumers either don't open or have technical difficulties navigating. In their assessments experts stand in full solidarity with the third characteristic for all companies: during the analysis there was no ambiguity in the interpretation of the information received. This aspect is important because the analysis of the reports was carried out by native Russian language speakers. In addition, medical information has certain specifics, which, however, is also easily perceived by experts. We cannot say that the characteristics of the information presented in the report of US medical companies on form $10-\mathrm{K}$ have high evaluations, but a large number of low evaluations are not recorded. In general there are wide opportunities for current and potential consumers to form a proper image of the company to choose one or another as a priority supplier of products.

\section{Conclusion}

Corporate reporting is an important element in the activities of modern companies. Not only the effectiveness but also the overall success of an activity depends on its qualitative performance. It appears that another function of corporate reporting can be attracting and retaining of potential and current consumers of products. This is especially important for those that operate in the social services. The results of the survey allowed us to determine that the most valuable information for the consumer is information about the safety of the company's activities, existing offices and divisions, including in other regions, as well as characteristics of the company's activities and products provided. The information content 
analysis of the most important sections for the consumer showed that not all medical companies in the United States have high quality information content. It seems that the presented conclusions can be of practical value for the activities of organizations in terms of organizing activities to attract consumers.

\section{References}

1. N. Prodanova, N. Plaskova, L. Popova, I. Maslova, I. Dmitrieva, J. Kharakoz, V. Sitnikova, Journal of Advanced Research in Dynamical and Control Systems, 8, 411 (2019)

2. D. Crowther, Urban Studies, 10, 1837 (2000)

3. Tenets of good corporate reporting (2018)

4. M. J. Milne, Accounting \& Business Research, 1, 83 (2003)

5. V. Sukhonos, I. Makarenko, Problems and Perspectives in Management, 1, 166 (2017)

6. J. H. Spangenberg, Journal of Cleaner Production, 134, 414 (2016)

7. Quest Diagnostics. Action from Insight. 2019 Annual Report on Form 10-K., https://www.annualreports.com/

8. Laboratory corporation of America holdings. United States securities and exchange commission. Form 10-K, https://ir.labcorp.com/

9. Express Scripts holding company. United States securities and exchange commission. Form 10-K, https://web.archive.org/

10. Cerner Corp. 2019. United States securities and exchange commission. Form 10-K, http://pdf.secdatabase.com/

11. DaVita Inc. 2019. Form 10-K Annual Report. U.S. Securities and Exchange Commission, https://www.sec.gov/

12. HCA Holdings, Inc. 2018. Form 10-K Annual Report. U.S. Securities and Exchange Commission, https://www.sec.gov/

13. Premier, Inc. 2015. Form 10-K Annual Report. U.S. Securities and Exchange Commission, https://www.sec.gov/

14. Tenet Healthcare Corporation. 2017. Form 10-K Annual Report. U.S. Securities and Exchange Commission, https://www.sec.gov/

15. Universal health services, Inc. FORM 10-K. Retrieved 13 May 2020. U.S. Securities and Exchange Commission, https://www.sec.gov/

16. Community Health Systems. FORM 10-K, https://last10k.com/ 